\title{
Czech Arts Therapies in Educational Institutions
}

\author{
Jiří Kantor*iD, Miroslav Chráska and Libuše Ludíková \\ Faculty of Education, University of Palacky in Olomouc, Žižkovo nám. 5, 77900 Olomouc, Czech Republic; \\ miroslav.chraska@upol.cz (M.C.); libuse.ludikova@upol.cz (L.L.) \\ * Correspondence: jiri.kantor@upol.cz; Tel.: +420-725-458-439
}

Received: 10 January 2019; Accepted: 9 April 2019; Published: 15 April 2019

\begin{abstract}
The purpose of this paper was to better understand the current practice of arts therapy in educational institutions in the Czech Republic comparing it to that in health-care institutions and other working environments. The research goal was to analyze the prevalence of the different fields of arts therapy, the main difficulties of clients, the therapeutic forms, the ways of interdisciplinary cooperation, and the groups of therapists (according to their age and duration of practice). The data collected from the first national survey using "The Practice of Arts Therapies" questionnaire were analyzed with descriptive and inductive statistics (Chi-square test). The 142 respondents who participated in the study were contacted mainly through professional associations. The significant characteristics of arts therapies in educational environments are linked to the diffusion of the respective arts therapy fields (music therapy being the most prevalent), the main difficulties of pupils (learning difficulties/multiple disabilities or no obvious problems), and to the length of practice of the respondents. The results can be used for the creation of a research-based map of Czech arts therapies in educational institutions and for further development of this area.
\end{abstract}

Keywords: arts; therapy; education; schools; art therapy; music therapy; drama therapy; dance therapy

\section{Introduction}

Educational institutions have been an important setting for the development of arts therapies. Many of the people central to the foundation of arts therapies, for example M. Naumburg, E. Kramer, F. Cane (art therapy), R. Laban (dance-movement therapy) and J. Alvin (music therapy), worked in the educational setting. Even now, many arts therapists work in educational institutions. An analysis of the specific features of this work environment may therefore be considered crucial for further development of arts therapies. So far, only a few systematic works on this topic have been written [1,2].

In the Czech Republic, arts therapies are most prevalent in educational and social care settings [3]. Despite this, understanding the application of arts therapies in educational settings is based on the experience of individual therapists rather than on systematic studies offering a research-based outline of the profession. A much-needed analysis in this area should aim to collect consistent data directly from the therapists' practice. Responding to these considerations, the authors designed and realized the first nation-wide survey into arts therapies using "The Practice of Arts Therapies" questionnaire by Karkou and Sanderson [4]. The aim of this survey was to create a research-based outline of arts therapies in Czech educational institutions. This contribution introduces partial results of this survey dealing with the specifics of arts therapies in educational settings. Such an outline may enable a comparison with foreign systems of arts therapies (in Great Britain, Latvia, or Estonia), an identification of culturally unique characteristics of therapeutic practices, and a systematic planning of the development of the community of arts therapists.

The main fields of arts therapies in the Czech Republic include (visual) art therapy, music therapy, drama therapy, and dance-movement therapy. These fields have the highest number of practicing 
therapists and are managed by professional associations [3]. Arts therapies are not registered as independent professions in the Czech Republic and are usually practiced as a supplement to other professions [5]. A large percentage of arts therapists in educational institutions nowadays have a primary qualification in special education or school psychology.

The traditional work environment of Czech arts therapists is a health-care institution [3]. The first glimpse of interest to apply art therapies in education was manifested for art therapy in the 1980s [6] and much later for music therapy and drama therapy. One analysis from Great Britain [4] suggests that the historical development of art therapies exerts some influence on certain factors characterizing the therapeutic practice in educational institutions, e.g., on age distribution and length of practice of arts therapists. Certain logical tendencies were found in the age distribution of therapists in educational settings (e.g., the decreasing number of young art therapists in educational institutions correlating with the fact that in the 1990s their professional development had been guided towards health-care institutions). The study also found a statistical correlation between the age and the length of service of British therapists [4].

The way arts therapies are applied in education is not clearly outlined. As for dance-movement therapy in Czech schools, Czech literature does not contain information about its existence. This does not necessarily mean, however, that the therapeutic application of dance and movement techniques is completely lacking. Arts experience in the sense of arts-centered education [7] is a common part of special education practice, while the line between arts-based pedagogy and arts therapies is often not clear, for example due to a double qualification of the professionals. Despite that, the need to differentiate between educational and therapeutic application of arts in schools is being constantly discussed. In art therapy, this has-towards the end of the 20th century-led to the formation of an independent pedagogy-related field called art philetics, defined as reflective and dialogic practice with art experience [8]. However, art philetics has been practiced mostly by art therapists, because both methods are taught in therapeutic trainings. While analyzing arts therapies in educational institutions, it is necessary to consider these related professions, since they intervene with the formation of a clear professional identity. This is especially true in the absence of legislative grounds for arts therapies.

In the past, most arts therapists in educational institutions typically operated in special schools or held arts therapy classes as part of rehabilitation [9], with the advantage of having an interdisciplinary team (e.g., physiotherapists, occupational therapists, speech therapists). It may be assumed that even nowadays - with the inclusive trends-most arts therapists in educational institutions work with children and youths with special educational needs [2]. However, in inclusive schools in the Czech Republic, health-care and other non-pedagogical professions are practically unavailable. Along with interdisciplinary collaboration, another advantage of the application of arts therapies in special schools is a better general knowledge of the special needs of pupils, which helps in the process of referral and communication of therapeutic outcomes.

Nowadays, the education of pupils with special educational needs in special institutions is diminishing in Czech schools (as in foreign countries). A new school law was enacted in 2016 in the Czech Republic that clearly establishes inclusive education as the preferred form of education for all pupils. This will probably greatly influence the forms of arts therapy in educational institutions. Foreign contributions show that the influence is reflected in the preference of therapeutic forms [10] resulting in the shifting from group and individual therapies (the classroom-withdrawal model) to consultative [11] and community therapy forms [12].

In some cases, multidisciplinary and interdisciplinary teamwork-the simultaneous cooperative work of arts therapists together with teachers, paraprofessionals, and those offering related services in the natural pedagogical and social environment of the pupil-is being replaced with the transdisciplinary perspective [13]. Such close collaboration, however, is sometimes limited by the need to maintain a safe environment, confidentiality, and safety of sensitive information, and to work with clients' strong emotions and deeply personal themes [14]. To overcome some of these obstacles, arts therapists sometimes create specific types of documentation, procedures, and principles [1]. 
These themes are at the core of what will be analyzed in the next sections, on the basis of the data acquired from Czech arts therapists. It is hoped that the understanding of the specifics of arts therapists' practice in educational institutions will help identify areas holding the greatest potential for sharing experience on a national and international level. A further aspiration is to determine ways of enhancing further development of therapeutic practices.

\section{Materials and Methods}

The aim of this study was to understand the practice of arts therapists in Czech educational institutions and to find out the specifics of their working environment. These specifics were identified through comparison with data related to arts therapies in other work environments and in health-care institutions that are traditionally connected to arts therapies [3]. This procedure was inspired by the methodology described by Karkou a Sanderson [4].

Aims:

- To determine the prevalence of the different fields of arts therapy in educational institutions.

- To identify clients' main difficulties.

- To establish which forms of therapies and types of interdisciplinary cooperation are dominant in the educational environment.

- $\quad$ To detect the distribution of arts therapists according to age and experience.

A quantitative methodology was applied for the collection and analysis of data using "The Practice in Arts Therapies" questionnaire by Karkou and Sanderson [4] and statistical analysis methods. The target population consisted of arts therapists in the Czech Republic, the total number of whom could be only roughly estimated on the basis of the current number of members in professional associations $(n=419)$. This number, however, includes also some non-practitioners. In 2017, there were 210 music therapists, 153 art therapists, 39 dance-movement therapists, and 17 drama therapists enrolled in associations. The rates of the respective arts therapists in the Czech Republic according to this data correspond approximately to the rates of individual fields in the research sample (Table 1).

Table 1. Numbers and rates of arts therapists enrolled in associations (2017) and of respondents $(n=142$ answers) according to arts therapy fields.

\begin{tabular}{ccccc}
\hline & \multicolumn{2}{c}{ In Associations (2017) } & \multicolumn{2}{c}{ Research Sample } \\
\hline Arts Therapy Fields & Number & Portion & $\begin{array}{c}\text { Number of } \\
\text { Respondents }\end{array}$ & Portion \\
\hline Music therapists & 210 & $50.1 \%$ & 50 & $35.2 \%$ \\
Art therapists & 153 & $36.5 \%$ & 38 & $26.8 \%$ \\
Combined therapy approach & N/A & N/A & 36 & $25.4 \%$ \\
Drama therapists & 17 & $4 \%$ & 9 & $6.3 \%$ \\
Dance-movement therapists & 39 & $9.3 \%$ & 9 & $6.3 \%$ \\
Total $(n)$ & 419 & $100 \%$ & 142 & $100 \%$ \\
\hline
\end{tabular}

The research sample was formed using non-probability sampling, specifically purposive sampling. Potential respondents had been approached through their professional associations. After that, this first line of respondents was asked to forward contact information of practicing arts therapists not registered in associations (using the snow-ball method). Participation in the research was anonymous and voluntary, and the participants were informed about its objectives in the headings of the questionnaire. Anonymity and confidence were kept throughout the process of data analysis and publication.

In the end, 142 respondents were included in the sample, some of whom were trainees with good therapeutic practice. Although the questionnaire offered space to include other specializations, these were not included in the statistical analysis because of low occurrence. Those respondents were excluded (five participants). The questionnaire allowed a multiple-choice answer for the specialization 
item. However, the chosen statistical analysis method did not allow the respondents to be included in more than one subgroup. Therefore, a new group was formed that was not included in the questionnaire originally: therapists using a combined therapy approach.

In order to enable the identification of the specifics of arts therapy practice in educational institutions, the sample was divided into a group of respondents who chose an educational institution to be their main workplace and a group of the remainder of respondents. Since the health-care environment and that of educational institutions are so markedly different, it was thought that comparing respondents coming from these two backgrounds might also bring noteworthy results. Henceforth, another subgroup was created, i.e., respondents working mainly in health-care institutions. Many arts therapists consider the educational and health-care environments contrasting, as is clear from their discussions on the topic [4]. Table 2 shows information about the level of respondents' qualification.

Table 2. The level of qualification of respondents according to their work environment (the rates in brackets show the relationship to the subsamples of the respective types of work environments).

\begin{tabular}{cccc}
\hline Work Environment & Full Qualification & Trainee & $\begin{array}{c}\text { Different Specialist } \\
\text { Using AT in Practice }\end{array}$ \\
\hline $\begin{array}{c}\text { Educational institutions } \\
\text { Other institutions (incl. }\end{array}$ & $18(35.3 \%)$ & $5(9.8 \%)$ & $27(52.9 \%)$ \\
health-care institutions) & $36(39.2 \%)$ & $22(24.2 \%)$ & $34(37.4 \%)$ \\
$\begin{array}{c}\text { Health-care institutions } \\
\text { Total }\end{array}$ & $13(38.2 \%)$ & $8(23.5 \%)$ & $13(38.2 \%)$ \\
\hline
\end{tabular}

Terms were defined in line with "The Practice in Arts Therapies" questionnaire. Arts therapies included: art therapy, drama therapy, music therapy, and dance-movement therapy. The term 'client' included various types of populations the therapists were working with (patients, children, pupils, adults, seniors, etc.). The clients' difficulties were divided into seven groups in the questionnaire: learning difficulties (e.g., autistic spectrum disorders, ADHD (Attention Deficit/Hyperactivity Disorder), speech and communication disorders), mental health problems (e.g., schizophrenia, depression, dementia, self-harming behaviors), social deprivation (e.g., prisoners, persons with social disadvantages, immigrants, refugees, homeless persons), medical problems (e.g., cancer, AIDS/HIV, chronic pain), physical/sensory difficulties, multiple difficulties, and no apparent/specific difficulty (e.g., stress-related, low self-confidence, problems related to creativity and personal growth).

The forms of therapy were divided into individual, group, and family/couples' therapy. In terms of ways of collaboration, the questionnaire recognizes working alone, collaborating with other professionals, and collaborating with other arts therapists.

Items related to information about respondents inquired about gender, age, experience, education, and professional qualifications. Five groups were created based on the age of the respondents: up to 30 years of age, 31-40, 41-50, 51-60, over 61. According to experience (length of practice in years), these categories were formed: up to 3 years of practice, $4-7$ years, $8-11$ years, $12-15$ years, and over 15 years.

Arts therapists were divided into four categories, according to their qualification: fully qualified arts therapist practicing in the field, fully qualified arts therapist not practicing in the field, student in a professional training program, other specialist using arts therapies techniques. A fully-qualified and practicing therapist was considered someone fulfilling all the professional requirements of the respective associations. Because of the character of training of arts therapists in the Czech Republic, the original questionnaire options were somewhat customized to include therapists who followed short-term courses and/or seminars with no formal training (usually up to $100 \mathrm{~h}$ ), those who followed long-term courses without formal training (but sufficient to fulfil the membership requirements of associations), those having a bachelor degree, master degree, or doctoral degree.

Data analysis was carried out using descriptive and inductive statistics methods in the Statistica 12 and Excel MS programs. Absolute and relative rates were calculated using descriptive statistics, 
which enabled a basic comparison of the respective subsamples. Since some questionnaire items enabled multiple choices of answers, there was a difference between the number of answers and the number of respondents. In these cases, relative rates were counted using the method described in an original work by Karkou and Sanderson [4], which made comparison simpler. The percentage rates in these cases of sub samples were not counted on the basis of the number of respondents but, rather, on the number of answers.

Moreover, statistical significance of the relationships between several variables was tested using induction statistics methods. This paper focused on the results of the analysis using the non-parametric Pearson's Chi-squared test [15]. Pearson Chi-square is based on the fact that we can compute the expected frequencies from the observed frequencies in a two-way table. The expected frequencies are those frequencies that we would expect if there was no relationship between the variables. The value of the Chi-square and its significance level depend on the overall number of observations and the number of cells in the table. The assumption underlying the use of the Chi-square is that the expected frequencies are not very small. Usually, $80 \%$ of cells should be $>5$. Yates correction was used in this study for tables with rates lower than allowed [16].

\section{Results}

The results and their interpretation are organized according to the research aims stated above. The sub chapters introduce the themes of prevalence of arts therapies fields in educational institutions, the most prevalent client groups in terms of age and difficulties, forms of therapies, types of interdisciplinary cooperation, and distribution of arts therapists according to age and experience.

\subsection{Prevalence of the Different Arts Therapy Fields}

The prevalence of the different arts therapy (AT) fields in educational institutions and their comparison with the prevalence in other institutions and health-care institutions are shown in Table 3. The most spread arts therapy field in educational environment appeared to be music therapy, while art therapy and combined therapy approaches came second, and drama therapy and dance-movement therapy were last. It is also clear that the field that is more prevalent in health-care institutions compared to the educational workplaces is dance-movement therapy. This comparison suggests that music therapists and art therapists have the largest experience to offer to enhance the work and development of other arts therapy fields in educational settings, for example in the form of good practice examples.

Table 3. The prevalence of the different arts therapy fields in each work environment in absolute numbers (the numbers in brackets show, in this order, the respective proportion in the whole sample where $n=142$ and in the total number of respondents in the respective arts therapy field).

\begin{tabular}{cccc}
\hline Arts Therapy Field & $\begin{array}{c}\text { Educational } \\
\text { Institutions }\end{array}$ & $\begin{array}{c}\text { Other Than Educational } \\
\text { Institutions (Inc. } \\
\text { Health-Care) }\end{array}$ & $\begin{array}{c}\text { Health-Care Institutions } \\
\text { (Percentages Show the Proportions } \\
\text { in Subsample “Other") }\end{array}$ \\
\hline Music therapy & $20(40 \%)$ & $30(60 \%)$ & $7(20.6 \%)$ \\
Art therapy & $14(36.8 \%)$ & $24(63.2 \%)$ & $9(26.5 \%)$ \\
Dramatherapy & $2(22.2 \%)$ & $7(77.8 \%)$ & $3(33.3 \%)$ \\
Dance-movement therapy & $1(11.1 \%)$ & $8(88.9 \%)$ & $5(55.6 \%)$ \\
Combined therapy approach & $14(38.8 \%)$ & $22(61.1 \%)$ & $10(27.8 \%)$ \\
Total & 51 & 91 & 34 \\
\hline
\end{tabular}

\subsection{The Main Difficulties of Clients}

Groups of clients of arts therapists were characterized according to their main difficulties (Table 4). It is evident that arts therapists in educational institutions mostly deal with clients with learning disorders and combined disorders (the term multiple disabilities better reflects the current terminology in educational legislative documents). As compared to other groups (in arts therapy institutions other 
than educational and in health-care institutions) the group of clients with no obvious/specific problem was much more dominant, which might be related to the fact that therapists work mostly in regular (inclusive) schools.

Table 4. Prevalence of various groups of clients according to the types of work environment $(100 \%=381$ answers $)$.

\begin{tabular}{cccc}
\hline Client Groups & $\begin{array}{c}\text { Educational } \\
\text { Institutions }\end{array}$ & $\begin{array}{c}\text { Other Than Educational } \\
\text { Institutions (Inc. } \\
\text { Health-Care) }\end{array}$ & $\begin{array}{c}\text { Health-Care Institutions } \\
\text { (Percentages Show the Proportions } \\
\text { in Sub Sample “Other") }\end{array}$ \\
\hline Learning difficulties & $37(26.6 \%)$ & $40(16.5 \%)$ & $13(13.7 \%)$ \\
Physical/sensory difficulties & $16(11.5 \%)$ & $31(12.8 \%)$ & $13(13.7 \%)$ \\
Mental health problems & $17(12.2 \%)$ & $53(21.9 \%)$ & $26(27.3 \%)$ \\
Multiple difficulties & $24(17.3 \%)$ & $45(18.6 \%)$ & $11(11.6 \%)$ \\
Social deprivation & $17(12.2 \%)$ & $31(12.8 \%)$ & $13(13.7 \%)$ \\
Medical problems & $11(7.9 \%)$ & $32(13.2 \%)$ & $16(16.8 \%)$ \\
No apparent/specific difficulty & $17(12.2 \%)$ & $10(4.1 \%)$ & $3(3.2 \%)$ \\
Total & 139 & 242 & 95 \\
\hline
\end{tabular}

\subsection{Forms of Therapy and Interdisciplinary Collaboration}

From the data, it appeared that the work environment does not exert a statistically significant influence on the preference of therapy form (Table 5). However, it should be remembered that the questionnaire did not contain items related to the less common and newer forms of therapy, especially community-based therapy.

Table 5. Forms of therapy according to the work environment of arts therapists $(100 \%=235$ answers $)$.

\begin{tabular}{cccc}
\hline Type of Therapy & $\begin{array}{c}\text { Educational } \\
\text { Institutions }\end{array}$ & Other Than Educational & $\begin{array}{c}\text { Health-Care Institutions } \\
\text { (Percentages Show the Proportions } \\
\text { in Subsample “Other") }\end{array}$ \\
\hline Group therapy & $41(51.2 \%)$ & $75(48.4 \%)$ & $27(50 \%)$ \\
Individual therapy & $30(37.5 \%)$ & $60(38.7 \%)$ & $19(35.2 \%)$ \\
Family/couples & $9(3.8 \%)$ & $20(8.5 \%)$ & $8(3.4 \%)$ \\
Total & $80(100 \%)$ & $155(100 \%)$ & $54(100 \%)$ \\
\hline
\end{tabular}

As to the ways of collaboration, it is obvious from the results that arts therapists in educational institutions mainly work alone. This fact suggests that therapy is carried out mostly separately outside of the educational process. Czech arts therapists in educational environments probably prefer the more traditional withdrawal model (working in a therapeutic environment separated from the pupil's class) than the recent transdisciplinary and community-based trends. Comparing data from educational and other work environments, the differences are minor (Table 6).

Table 6. Forms of collaboration according to the work environment of the therapists $(100 \%=$ 200 answers).

\begin{tabular}{cccc}
\hline Type of Therapy & $\begin{array}{c}\text { Educational } \\
\text { Institutions }\end{array}$ & Other Than Educational & $\begin{array}{c}\text { Health-Care Institutions } \\
\text { (Percentages Show the Proportions } \\
\text { in Sub Sample “Other”) }\end{array}$ \\
\hline $\begin{array}{c}\text { Working alone } \\
\begin{array}{c}\text { Collaboration with } \\
\text { other professionals }\end{array}\end{array}$ & $40(60.6 \%)$ & $67(50 \%)$ & $25(45.6 \%)$ \\
$\begin{array}{c}\text { Collaboration with } \\
\text { other arts therapists }\end{array}$ & $6(30.3 \%)$ & $49(36.6 \%)$ & $21(38.2 \%)$ \\
Total & $66(100 \%)$ & $18(13.4 \%)$ & $9(16.4 \%)$ \\
\hline
\end{tabular}




\subsection{Age and Experience of the Therapists}

The hypothesis for this statistical analysis was based on the expectation that arts therapists in educational institutions would be characterized by a shorter duration of practice and a younger age, especially when compared to arts therapists in health-care institutions. This expectation was based on the historical development of arts therapies, since arts therapies began to be applied in educational institutions later than in health-care settings. Nevertheless, the preliminary statistical analysis carried out before the conceptualization of research problems proved [5] that age and experience in the Czech sample were not statistically related to each other. Hence, it was necessary to test the two factors separately. The duration of practice of arts therapists was categorized into five subcategories based on several questionnaire items, as shown in Tables 7 and 8. Differences between expected and observed numbers of respondents for the respective age and experience sub-categories were measured using the Chi-square test. This test enabled to determine statistical significance in the whole dataset. For the identification of cells of the table in which the relationship was the most significant, it was necessary to determine the difference between measured and expected rates in each table cell and determine which differences were greatest. Statistical differences were tested at the significance level of $p=0.05$.

Table 7. Observed (O) versus expected (E) numbers: years of practice in categories and number of therapists according to the type of workplace (comparison of educational institutions and all other types of workplace).

\begin{tabular}{|c|c|c|c|c|c|c|c|c|c|c|c|}
\hline \multirow{3}{*}{ Type of Workplace } & \multicolumn{10}{|c|}{ Years of Practice in Categories } & \multirow{3}{*}{ Total } \\
\hline & \multicolumn{2}{|c|}{3 and Less } & \multicolumn{2}{|c|}{$4-7$} & \multicolumn{2}{|c|}{$8-11$} & \multicolumn{2}{|c|}{$12-15$} & \multicolumn{2}{|c|}{ Over 15} & \\
\hline & $\mathbf{O}$ & E & $\mathrm{O}$ & E & $\mathrm{O}$ & E & $\mathbf{O}$ & E & $\mathrm{O}$ & E & \\
\hline Educational institutions & 11 & 12.21 & 19 & 14.73 & 14 & 9.34 & 3 & 6.46 & 4 & 8.26 & 51 \\
\hline Other than educational & 23 & 21.79 & 22 & 26.27 & 12 & 16.66 & 15 & 11.54 & 19 & 14.74 & 91 \\
\hline All institutions & \multicolumn{2}{|c|}{43} & \multicolumn{2}{|c|}{41} & \multicolumn{2}{|c|}{26} & \multicolumn{2}{|c|}{18} & \multicolumn{2}{|c|}{23} & 142 \\
\hline
\end{tabular}

Table 8. Observed $(\mathrm{O})$ and expected numbers (E): practice duration in categories and number of therapists according to the type of workplace (comparison of educational and health-care institutions).

\begin{tabular}{|c|c|c|c|c|c|c|c|c|c|c|c|}
\hline \multirow{3}{*}{ Type of Workplace } & \multicolumn{10}{|c|}{ Years of Practice in Categories } & \multirow{3}{*}{ Total } \\
\hline & \multicolumn{2}{|c|}{3 and Less } & \multicolumn{2}{|c|}{$4-7$} & \multicolumn{2}{|c|}{$8-11$} & \multicolumn{2}{|c|}{$12-15$} & \multicolumn{2}{|c|}{ Over 15} & \\
\hline & $\mathrm{O}$ & $\mathbf{E}$ & $\mathrm{O}$ & $\mathbf{E}$ & $\mathrm{O}$ & $\mathrm{E}$ & $\mathbf{O}$ & $\mathrm{E}$ & $\mathrm{O}$ & E & \\
\hline Educational institutions & 11 & 11.4 & 19 & 13.2 & 14 & 12.6 & 3 & 6.6 & 4 & 7.2 & 51 \\
\hline Health-care institutions & 8 & 7.6 & 3 & 8.8 & 7 & 8.4 & 8 & 4.4 & 8 & 4.8 & 34 \\
\hline All institutions & \multicolumn{2}{|c|}{19} & \multicolumn{2}{|c|}{22} & \multicolumn{2}{|c|}{21} & \multicolumn{2}{|c|}{11} & \multicolumn{2}{|c|}{12} & 85 \\
\hline
\end{tabular}

\section{Hypotheses concerning the relationship between work environment and experience:}

H1. There is a statistically significant difference between years of practice of the arts therapists mainly working in educational institutions and those working in other types of settings.

H2. There is a statistically significant difference between years of practice of the arts therapists mainly working in educational institutions and those working in health-care institutions.

The observed and expected numbers related to the years of practice in the different workplaces are shown in Table 7 (educational institutions vs other than educational) and Table 8 (educational institutions vs health-care institutions).

Educational institutions versus other types of workplaces $\left(\mathrm{H}_{1}\right)$ : The significance level $p<0.01$ $(p=0.017)$ suggests that the type of workplace and the duration of arts therapists' practice are related. In educational institutions, the prevalence of arts therapists with over 11 years of practice was lower than expected, while the sub-category 3-11 years of practice had a very high prevalence. The results 
suggest that in the Czech Republic, arts therapists have started to be more broadly employed in educational institutions over the last 10 years, and their numbers have since been relatively stable with no significant changes over the last 3 years.

Educational institutions versus health-care institutions $\left(\mathrm{H}_{2}\right)$ : In this case, the significance level of $p<0.01(p=0.004)$ also proved statistical significance. There was a relationship between the type of workplace and the duration of practice of the therapists. The greatest difference was measured for the sub-category 4-7 years of practice. The next highest difference was found in the 12-15 sub-category and over 15 sub-category (see Table 8). In educational institutions, we found therapists with a shorter duration of practice than in health-care institutions, which corresponds with the results above.

\section{Hypotheses concerning the relationship between work environment and age of arts therapists:}

H3. There is a statistically significant difference between the age of the arts therapists mainly working in educational institutions and the age of those working in other types of settings.

H4. There is a statistically significant difference between the age of the arts therapists mainly working in educational institutions and the age of those working in health-care institutions.

These hypotheses explored the relationship between age and workplaces of the therapists. As the above-mentioned result indicate that a relationship exists between workplace and years of practice, it may be assumed a similar result would be obtained in this case too. Age and experience are logically related. The observed and expected numbers when testing the age of therapists in the different workplaces are shown in Table 9 (educational institutions vs other than educational) and Table 10 (educational institutions vs health-care institutions).

Table 9. Observed $(\mathrm{O})$ vs expected (E) numbers: age of arts therapists and number of therapists according to the type of workplace (comparison of educational and all other types of workplaces).

\begin{tabular}{|c|c|c|c|c|c|c|c|c|c|c|c|}
\hline \multirow{3}{*}{ Type of Workplace } & \multicolumn{10}{|c|}{ Age of Therapists in Categories } & \multirow{3}{*}{ Total } \\
\hline & \multicolumn{2}{|c|}{$\begin{array}{c}\text { Less Than } \\
30\end{array}$} & \multicolumn{2}{|c|}{$31-40$} & \multicolumn{2}{|c|}{$41-50$} & \multicolumn{2}{|c|}{$51-60$} & \multicolumn{2}{|c|}{ Over 61} & \\
\hline & $\mathrm{O}$ & $\mathbf{E}$ & $\mathrm{O}$ & $\mathbf{E}$ & $\mathbf{O}$ & $\mathbf{E}$ & $\mathrm{O}$ & $\mathrm{E}$ & $\mathbf{O}$ & E & \\
\hline Educational institutions & 7 & 8.3 & 18 & 15.1 & 19 & 18 & 5 & 5.4 & 2 & 4.3 & 51 \\
\hline Other than educational & 16 & 14.7 & 24 & 26.9 & 31 & 32 & 10 & 9.6 & 10 & 7.7 & 91 \\
\hline All institutions & \multicolumn{2}{|c|}{23} & \multicolumn{2}{|c|}{42} & \multicolumn{2}{|c|}{50} & \multicolumn{2}{|c|}{15} & \multicolumn{2}{|c|}{12} & 142 \\
\hline
\end{tabular}

Table 10. Observed (O) vs expected (E) numbers: age of arts therapists and number of therapists according to the type of workplace (comparison of educational and health-care institutions).

\begin{tabular}{|c|c|c|c|c|c|c|c|c|c|c|c|}
\hline \multirow{3}{*}{ Type of Workplace } & \multicolumn{10}{|c|}{ Age of Therapists in Categories } & \multirow{3}{*}{ Total } \\
\hline & \multicolumn{2}{|c|}{$\begin{array}{c}\text { Less Than } \\
30\end{array}$} & \multicolumn{2}{|c|}{$31-40$} & \multicolumn{2}{|c|}{$41-50$} & \multicolumn{2}{|c|}{$51-60$} & \multicolumn{2}{|c|}{ Over 61} & \\
\hline & $\mathbf{O}$ & E & $\mathrm{O}$ & E & $\mathbf{O}$ & $\mathbf{E}$ & $\mathrm{O}$ & $\mathrm{E}$ & $\mathbf{O}$ & E & \\
\hline Educational institutions & 6 & 7.8 & 18 & 14.4 & 19 & 21 & 5 & 5.4 & 2 & 2.4 & 51 \\
\hline Health-care institutions & 7 & 5.2 & 6 & 9.6 & 16 & 14 & 4 & 3.6 & 2 & 1.6 & 34 \\
\hline All institutions & \multicolumn{2}{|c|}{13} & \multicolumn{2}{|c|}{24} & \multicolumn{2}{|c|}{35} & \multicolumn{2}{|c|}{9} & \multicolumn{2}{|c|}{4} & 85 \\
\hline
\end{tabular}

Educational institutions vs other types of workplaces $\left(\mathrm{H}_{3}\right)$ : The significance level $p>0.05$ $(p=0.517)$ revealed that the type of workplace was not significantly related to the age of arts therapists. The age of arts therapists in educational institutions did not differ from the age of arts therapists in all other workplaces, although partial differences existed in the age sub categories of 31-40 years and over 61 years (Table 9 ).

Educational institutions vs health-care institutions $\left(\mathrm{H}_{4}\right)$ : The significance level $p>0.05(p=0.529)$ also reveals that, currently, the type of workplace is not significantly related to the age of arts therapists. 
The age of arts therapists in educational institutions dis not differ from the age of arts therapists in a health-care environment. The greatest differences were seen for the 31-40 sub-category.

\section{Discussion}

This section will elaborate on the interpretation of the results with regard to the theoretical background, suggestions for further research, activities for future practice of arts therapies, and reflection on the strengths and weaknesses of this research.

\subsection{Prevalence of the Different Art Therapy Fields}

The most prevalent art therapy field found in educational institutions was music therapy, followed by art therapy and combined therapy approach, while drama therapy and dance-movement therapy were used only to a small extent, which is further decreasing. In the case of dance-movement therapy, this is logical, as training modules have so far only included some work on the issue of the educational environment. Although there were few drama therapists and dance-movement therapists in the sample, the discussions with dance-movement therapists proved these conclusions to be rather accurate (based on the discussion at the annual meeting of the Association of Dance-Movement Therapy on 13 May 2017). This could not be ascertained in the case of drama therapy, since data were not sufficient.

Moreover, the current trends in dance-movement therapy are directed towards a gradual increase of interest in educational institutions, which might be associated with the recent international relations in training programs. Regarding music and art therapists, nowadays, educational institutions are among the core types of workplaces and play a crucial role in forming the identity of these professions.

When compared to similar international studies, it is clear that educational institutions are also important work environments for music therapy in Great Britain [4] and Latvia [1,17]. Studies among art therapists in Russia [4] also offer similar conclusions, since educational institutions have significantly outgrown private practice as well as health-care institutions. A complete opposite situation with respect to that in the Czech Republic may be seen in the fact that British dance-movement therapy is the most prevalent in educational institutions [4]. When compared to the situation in neighboring countries, there is a similarity with Slovakia, where arts therapies are often present in educational institutions because of their inclusion in the Heilpädagogik (curative education) curriculum which is part of the study program in educational courses [18]. In other neighboring countries, the situation varies, e.g., Austria has a great psychotherapy orientation not only in music therapy [19] but also in the other arts therapies.

\subsection{Main Difficulties}

Arts therapists in educational institutions work mainly with children and youths. With regard to the types of difficulties of the clients in educational institutions, there is a dominance of learning difficulties and multiple difficulties. Similar results may be found for music therapists in Great Britain [4] and Latvia [17]; in other areas of British arts therapies, the focus is more related to pupils with emotional and behavioral problems [4]. In the Czech sample, a comparison with the rates of the types of difficulties in other work environments and educational institutions also showed a high occurrence of having to deal with clients with no obvious or non-specific difficulties. One possible explanation is that arts therapists are employed in inclusive (typical) schools.

Again, dance-movement therapy stands out in that (in line with the original training emphasis) it focuses primarily on the adult population and psychiatric/medical problems. Today, dance-movement therapy training programs are starting to involve lecturers oriented towards working with children. Just as in the case of other arts therapy specializations, a gradual expansion of the therapeutic practice already occurring in the current training programs may be expected. 


\subsection{Therapeutic Process: Forms of Therapy and Collaboration}

Educational institutions do not show any difference in their preferred forms of therapy in comparison with other workplaces. Just as in other work environments, there is a high prevalence of group therapy and more limited use of individual or family therapies. A community form of therapy that is typical for educational institutions $[12,20]$ and, according to some contributions, is also present in the Czech Republic [21] was not included in the questionnaire. We suggest that it should be the focus of further research.

The educational environment uses interdisciplinary collaboration less commonly than in other types of workplaces, which might be caused by a lower availability of other professionals in schools. The differences, however, are small, and there would probably not be any statistical significance if they were examines. Nevertheless, it is possible to deal with problems that stem from the lower availability of teams in educational institutions [1]. Teamwork is highly appreciated for the possibilities it offers for the evaluation and assessment of clients [22]. Assessment instruments as substitutes for other specialist examinations are not widely used in the practice of Czech arts therapists, nor are any standardized procedures to identify therapeutic needs and diagnose special educational needs [23]. The lack of these instruments could soon be the subject of interest of professional associations as well as students of arts therapies. Moreover, with the growing application of inclusion, a need to develop team collaboration methods in regular schools is rising [24]. The absence of medical staff in these teams might present an obstacle for arts therapists who will be forced to look for other solutions.

\subsection{Characteristics of Therapists (Age and Length of Practice) in Educational Institutions}

A statistically significant difference was found in the length of practice of arts therapists in educational institutions compared both to health-care institutions and to all other (non-educational) types of workplaces. The therapists' age was not found to be significant, contradicting the conclusions of an original study made in Great Britain [4]. It seems students enter educational programs in arts therapies at various ages in relation to the postgraduate qualification that is typical for the Czech arts therapies. This may be enhanced by different legislative stances of arts therapies in both countries.

In educational institutions, we found therapists with a shorter length of practice. This finding may be explained by the fact that educational institutions have only recently started to accept arts therapists more broadly. It is also possible that educational institutions serve as a work training environment for many beginning therapists, enabling them to fulfil the more difficult requirements of health-care institutions. This explanation would, however, need more supportive information on whether the therapists actually transfer to health-care institutions after a period of time, or whether the choice of the work environment is given by their primary qualification that may be medical, educational, or other.

In all cases, however, the shorter average length of practice of arts therapists in educational institutions requires greater attention towards the professional growth of arts therapies in this work environment, in order to balance the quality of therapeutic practice with that of other types of workplaces (especially health-care institutions). For example, because of the close relationship of therapeutic practice to various primary qualifications, it is important for arts therapists to learn to be sensitive towards differences in pedagogical and therapeutic applications of arts [7,25]. In the process, it is crucial to remember-because of the different work contexts - the different requirements for therapists to achieve professional status, their therapeutic competencies, system inclusion, and other factors.

\subsection{Summary of the Recommendations}

- Music therapists, as a result of their strongest affiliation with educational institutions, may present as a group that is most likely to offer inspiration for the practice of other therapists working in educational institutions. Further research should aim to identify good practice examples.

- Dance-movement therapists may begin discussions about the possibilities of supporting training as well as practice in non-clinical application of their therapy. This study suggests possible themes 
of the therapeutic practice in educational institutions and its use with children and youths with special educational needs. Experience may be drawn, for example, from British dance-movement therapy that is strongly oriented towards educational institutions [26].

- Further research may focus on the analysis of community-based therapy and transdisciplinary team collaboration, both of which might become increasingly central with the growing emphasis on inclusive education. The authors suggest supplementing "The Practice of Arts Therapies" questionnaire with items reflecting these newer therapeutic trends.

- A lower length of practice for therapists in educational institutions (compared to other work settings) corresponds to lower therapeutic experience. This may not, however, correspond to a lower quality of therapy [27]. The authors assume, on the basis of their own knowledge of arts therapies in educational institutions, that in the Czech Republic, the therapeutic procedures and strategies are not sufficiently developed though, according to foreign authors [13], they reflect the crucial characteristics of this work environment. Further research, e.g., in the form of qualitative analysis, might bring more detailed information on this topic.

In the future, one positive step may be establishing a stronger cooperation between arts therapists in clinical and nonclinical environments. The ground/basal qualifications of arts therapists in education and health-care are different in most cases. Because of strongly defined workplace identities in the Czech Republic, there are negative feelings towards arts therapists without the clinical specialization required in health care. The authors suggest these conflicting attitudes may ease if arts therapies used in educational institutions are clearly defined, if the specifics of therapeutic practice in educational institutions are outlined, and if the integration of arts therapies into special education areas is theoretically and professionally proven. These requirements demand further research however, but certain practical steps based on the described conclusions may be already undertaken.

Strengths and weaknesses of the study are shown in Table 11. The authors attempted to reflect on the course of the research as well as on the possibility of the immediate application of their results in theory, practice, and professional training of arts therapists. There is a possibility to discuss these results in larger forums (e.g., during professional association meetings in order to enhance a constructive dialogue between researchers and practicing therapists).

Table 11. Reflection of strengths and weaknesses of this research.

\begin{tabular}{lll}
\hline & \multicolumn{1}{c}{ Strengths of the Research } & \multicolumn{1}{c}{ Weaknesses of the Research } \\
\hline $\begin{array}{l}\text { Scientific } \\
\text { background }\end{array}$ & $\begin{array}{l}\text { Adding expert literature in Czech and Slovak } \\
\text { languages that is not available in English } \\
\text { Using other than written sources, e.g., } \\
\text { community discussion on a national and } \\
\text { international level }\end{array}$ & $\begin{array}{l}\text { Lack of information about some examined } \\
\text { phenomena published in English, especially } \\
\text { those related to detailed information about } \\
\text { the practice of arts therapists in educational } \\
\text { institutions }\end{array}$ \\
$\begin{array}{lll}\text { Participants/ } \\
\text { sampling }\end{array}$ & $\begin{array}{l}\text { Using personal contacts for respondents' } \\
\text { enrolment }\end{array}$ & $\begin{array}{l}\text { Lower number of respondents compared to } \\
\text { the sampling plan } \\
\text { Difficulty in setting the inclusion criteria } \\
\text { related to the professional identity of the } \\
\text { respondents }\end{array}$ \\
\hline Data collection & $\begin{array}{l}\text { Using a questionnaire that has been used in a } \\
\text { range of international researches }\end{array}$ & $\begin{array}{l}\text { The questionnaire does not reflect some new } \\
\text { trends in arts therapies. Changes suggested. }\end{array}$ \\
\hline Data analysis & - & $\begin{array}{l}\text { The use of mostly descriptive statistics and } \\
\text { non-parametrical tests with a lower validity }\end{array}$ \\
\hline Results application & $\begin{array}{l}\text { The ease of establishing a dialogue with the } \\
\text { community for which the results are meant } \\
\text { The possibility to consult the generalizations } \\
\text { and application of the conclusions }\end{array}$ & $\begin{array}{l}\text { The conclusions may be influenced by the } \\
\text { number of participants and the method of } \\
\text { their selection. } \\
\text { Data collection and analysis need to be } \\
\text { repeated }\end{array}$ \\
\hline
\end{tabular}




\section{Conclusions}

In the comparison section of the analysis, it was noted that music therapy is the form of art therapy that is currently most broadly applied in educational institutions. At the other end of the scale is dance-movement therapy that has only sporadically been applied in educational settings and whose main client groups are very different from those of other arts therapies.

With regards to the analysis of the preferences of forms of therapy and team collaboration, there were no significant differences between the educational setting and other settings. However, the results still show a somewhat decreased availability of team collaboration that needs to be addressed during the professional training of future therapists (e.g., in the areas of assessment and evaluation of the therapeutic process). The authors suggest focusing future research on the application of community forms of therapy and the use of transdisciplinary perspectives in the therapeutic process.

The analysis of the distribution of age and experience of the therapists showed that only the length of practice in years is a statistically significant factor when comparing educational institutions with other work environments. The result may be logically explained by the historical development of arts therapies in the Czech Republic, which were first applied in the health-care system and only later spread to the education sector.

These conclusions may benefit fields of professional training and supervision in arts therapies. Arts therapists working in schools have a much more profound need to master certain specific skills in order to use the therapeutic processes that are usually the domain of doctors and other health-care personnel in clinical settings. The skills include, for example, the assessment/evaluation process [13] and the preparation of a therapeutic plan. The professional standards for utilizing arts therapies in schools should be stricter than in health-care institutions. The current legislative requirements in the Czech Republic do not, however, reflect this fact, and, thus, professional associations should design guidelines for non-clinical settings. The high standard of arts therapies in schools is related to the existence of specific features that characterize this work environment [2]. For a satisfactory development of arts therapies in educational institutions, it is crucial to further explore the specifics of this work environment and educate the community of arts therapists, so that they are better able to take into account these specifics in the course of therapy.

Author Contributions: Conceptualization, J.K.; methodology, J.K. and M.C.; validation, J.K., M.C. and L.L.; formal analysis, J.K.; investigation, J.K.; resources, J.K.; data curation, J.K. and M.C.; writing-original draft preparation, J.K.; writing-review and editing, J.K. and L.L.; visualization, J.K.; supervision, L.L.; project administration, L.L.; funding acquisition, L.L.

Funding: IGA_2019_004-Výzkum muzikoterapie v oblasti rozvoje osob se speciálními potřebami [Research of music therapy in the development of persons with special needs]

Conflicts of Interest: The authors declare no conflict of interest. The funders had no role in the design of the study; in the collection; analyses; or interpretation of data; in the writing of the manuscript; or in the decision to publish the results.

\section{References}

1. Moriya, D. Art Therapy in Schools; Moria D.: Ramat Hasharon, Israel, 2011; pp. 33-46.

2. Karkou, V. Arts Therapies in Schools: Research and Practice; Jessica Kingsley Publishers: London, UK, 2010; pp. 271-279.

3. Kantor, J. Společné a Rozdilné v Uměleckých Kreativních Terapiích; Univerzita Palackého: Olomouc, Czech Republic, 2016; pp. 354-367.

4. Karkou, V.; Sanderson, P. Arts Therapies: A Research-Based Map of the Field; Elsevier: Edinburg, UK, 2006.

5. Kantor, J. Společné, Rozdílné a Jedinečné—Na Výzkumu Založená Mapa Profesí Uměleckých Terapií v České Republice s Akcentem na (Speciální) Vzdělávací Instituce. Habilitation Ph.D. Thesis, University of Palacky, Olomouc, Czech, 2018.

6. Slavík, J. Současná Arteterapie v České Republice a v Zahraničí Univerzita Karlova: Praha, Czech Republic, 2000; p. 8. 
7. Anderson, F.E. Art-Centered Education and Therapy for Children with Disabilities, 1st ed.; Charles C Thomas Publishers: Springfield, IL, USA, 1996; p. ix.

8. Slavík, J.; Škaloudová, B. Artefiletika-reflektivní pojetí výchovy uměním. Kriti. Listy 2001, 28. Available online: http://www.kritickemysleni.cz/klisty.php?co=28/!artfiletika (accessed on 10 February 2018).

9. Jankovský, J. Ucelená Rehabilitace Dětí s Tělesným a Kombinovaným Postižením, Somatopedická a Psychologická Hlediska, 2nd ed.; TRITON: Praha, Czech Republic, 2006; pp. 25-26.

10. Siegel, C.A. School Art Therapy. In The Wiley Handbook of Art Therapy, 1st ed.; Gussak, D.E., Rosal, M.L., Eds.; John Wiley \& Sons: West Sussex, UK, 2016; pp. 435-442.

11. Kern, P. Making friends in music: Including children with autism in an interactive play setting. Music Ther. Today Q. J. Stud. Music Music Ther. 2004, 5, 1-43.

12. McFerran, K.S.; Rickson, D. Community music therapy in schools: Realigning with the needs of contemporary students, staff and systems. Int. J. Community Music 2014, 7, 75-92. Available online: https://www.researchgate.net/profile/Katrina_Mcferran/publication/262775418_Community_music_ therapy_in_schools_Realigning_with_the_needs_of_contemporary_students_staff_and_systems/ links/5467fe480cf20dedafcf52fd/Community-music-therapy-in-schools-Realigning-with-the-needsof-contemporary-students-staff-and-systems.pdf (accessed on 21 November 2018). [CrossRef]

13. Johnson, F.L. Models of service delivery. In Models of Music Therapy Interventions in School Settings, 1st ed.; Wilson, B.L., Ed.; National Association for Music Therapy: Silver Spring, MD, USA, 1996; pp. 48-77.

14. Zeleiová, J.G. Psychodynamické Aspekty Muzikoterapie, 1st ed.; Trnavská Univerzita: Trnava, Slovakia, 2012; pp. 154-155.

15. Chráska, M. Metody Pedagogického Výzkumu. Základy Kvantitativního Výzkumu, 2nd ed.; Grada: Praha, Czech Republic, 2016; pp. 64-69.

16. Hendl, J. Přehled Statistických Metod Zpracování Dat, 1st ed.; Portál: Praha, Czech Republic, 2006; pp. $304-305$.

17. Paisca, I.; Martinsone, K.; Karkou, V. The Practice of Arts therapies in Latvia: Findings from a nation-Wide Survey. In Proceedings of the International Scientific Conference Art Therapy: Realities and Prospects, Šiauliai, Lithuania, 7 January 2013.

18. Kováčová, B. Liečebná pedagogika III, 1st ed.; Univerzita Komenského: Bratislava, Slovakia, 2015.

19. Music Therapy in Austria. Available online: https://www.emtc-eu.com/Austria (accessed on 12 December 2018).

20. Georgia, S.; Spencer, R.; Curtin, P.C. Umenia zo srdca: Vzt'ahovo-kulturálny prístup uplatňujúci arteterapiu so skupinou mestských stredoškoláčiek. Arteterapie 2013, 32, 22-33.

21. Kantor, J.; Weber, J. Komunitní aktivity a kreativní přístupy v sociální rehabilitaci osob s těžkým kombinovaným postižením. In Kreativní př́stupy v Rehabilitaci osob s Těžkým Kombinovaným Postižením, 1st ed.; Kantor, J., Ed.; Univerzita Palackého: Olomouc, Czech Republic, 2014; pp. 179-195.

22. Feder, B.; Cruz, R.F. Issues in Arts Therapies Evaluation. In The Art and Science of Evaluation in the Arts Therapies, 2nd ed.; Charles C Thomas Publisher: Springfield, IL, USA, 2013; pp. 246-265.

23. Brunk, B.K.; Coleman, K.A. A Special Education Music Therapy Assessment Process. In Models of Music Therapy Interventions in School Settings, 1st ed.; Wilson, B.L., Ed.; American Music Therapy Association, Inc.: Silver Spring, MD, USA, 1996; pp. 69-82.

24. Mitchell, D. What Really Works in Special and Inclusive Education, 2nd ed.; Routledge: London, UK, 2014; pp. 3-5.

25. Ayres, D. Defining Arts Integration. In Arts Integration in Education, 1st ed.; Mardirosian, G.H., Lewis, Y.P., Eds.; Intellect: Bristol, UK, 2016; pp. xi-xiv.

26. Karkou, V. Dance movement therapy: Introduction to basic theoretical and methodological principles; descriptive results from a research study completed in the UK. Sports Soc. 2001, 29, 45-53.

27. Vybíral, Z.; Roubal, J. Dnešní psychoterapie. In Současná Psychoterapie, 1st ed.; Vybíral, Z., Roubal, J., Eds.; Portál: Praha, Czech Republic, 2010; pp. 164-194.

(C) 2019 by the authors. Licensee MDPI, Basel, Switzerland. This article is an open access article distributed under the terms and conditions of the Creative Commons Attribution (CC BY) license (http://creativecommons.org/licenses/by/4.0/). 